\title{
Viability of Biogas Production from Manure/Biomass in Nigeria Using Fixed Dome Digester
}

\author{
A. I. Aigbodion, I. O. Bakare, E. A. Fagbemi*, E. O. Abolagba, \\ B. Omonigho, P. O. Ayeke, M. Bausa, E. Musa
}

Rubber Research Institute of Nigeria, Nigeria

Copyright $(2018$ by authors, all rights reserved. Authors agree that this article remains permanently open access under the terms of the Creative Commons Attribution License 4.0 International License

\begin{abstract}
Waste materials produced from agricultural products (such as crop residues, animal manure, and organic waste from Agro - industries dairy production) generally referred to as biomass constitute nuisance to the community as air, water and land pollutant if disposed without treatment. Anaerobic digestion of treating biomass is cheap, easier and economical compare to other methods of waste management like gasification. It produces methane $\left(\mathrm{CH}_{4}\right)$ gas used for cooking and lighting domestically and industrially while the digestate is a source of fertilizer. A fixed dome digester is built for anaerobic digestion of biomass (cow dung), the plant has digester, mixing tank, gas pipe, inspection tank, gas dome and manhole as major components. Other accessories are rubber hose, gas burner, gas filter and the gas lamp. Materials for the construction of the plant were sourced locally while the accessories were imported from India. Production of biogas through anaerobic digestion improves fertilization efficiency and environmentally sound waste recycling.
\end{abstract}

Keywords Biogas, Biomass, Dome, Digester, Fixed, Viability

\section{Introduction}

Biogas is the gas produced from the digestion of organic materials under anaerobic condition. Anaerobic digestion takes place in the presence of moisture and absence of oxygen. The biogas is mainly a mixture of methane $\left(\mathrm{CH}_{4}\right)$ and carbon dioxide $\left(\mathrm{CO}_{2}\right)$ with traces of Hydrogen $\left(\mathrm{H}_{2}\right)$, Hydrogen Sulphide $\left(\mathrm{H}_{2} \mathrm{~S}\right)$ and Nitrogen $\left(\mathrm{N}_{2}\right)$.

Substrate such as domestic (communal) organic waste, green plant waste, communal sewage sludge, liquid or solid manure are transferred into methane and carbon dioxide through anaerobic digestion process. By percentage composition, biogas has 50-75\% Methane, 25-50\% Carbon dioxide, 0 - 10\% Nitrogen, 0 - 1\% Hydrogen Sulphide, and $0-2 \%$ Oxygen [1].

Anaerobic digestion is a purely bacterial process which involves four phases; Hydrolysis, Acidification, Acetification and Methanogenesis phase. For anaerobic digestion to take place, anaerobic Milier bacteria must be present at $15^{\circ} \mathrm{C}$ and $55^{\circ} \mathrm{C}$ with $\mathrm{PH}$ value of 6.5 and 8.0 [2]. To increase productivity, the feedstock must not be big in size and must be free of retardant, heavy metal salt, antibiotics and disinfectant.

Biogas production is sustainable, renewable and carbon neutral. It reduces emission of methane which is also a green gas. Biogas production improved fertilization efficiency, reduces nuisance from odour and flies, it brings about cheap and environmentally sound waste recycling [3]. Basically, biogas plant consists of a digester or fermentation tank, gas holder or dome, inlet and mixing tank, gas pipe and displacement tank. Other accessories are; rubber hose, biogas gas burner, gas filter, and gas lamp. Digester or fermentation tank is a crucial component of biogas plant that provides the anaerobic condition in which the bacteria generate biogas. The gas holder cuts off the air to the digester and collects the gas generated. It could be floating (India dome) or fixed (Chinese dome). Floating drum sink into the slurry due to its own weight and on the ring constructed inside a digester or allows floating inside a water jacket [4]. When the gas is generated, the gas holder rises and floats freely.

Fixed dome vault or gas holder is usually buried under the ground completely. The biogas is collected in the restricted space of the gas dome, hence has high pressure. As mentioned, biogas plant can be classified based on the gas holder design. If the dome vault is fixed is referred to as fixed dome digester and if is a floating dome is called floating dome digester plant [2].

The plant (biogas) can also be classified based on method of feeding/loading or charging of the substrate as batch flow, continuous flow, plug flow and contact flow. Batch flow biogas digester plant is the one in which the 
digester is loaded at once, maintained closed for a convenient period, the organic material is fermented and is then unloaded at a later time, and charged with new biowaste. This is mostly suitable for dry organic matter (solid materials) such as vegetable waste, cow dung, and waste from pig etc. Batch flow digester is best operated in groups because it slowly starts producing biogas and increases the production with time and then drop - off after 4-8 weeks [2].

In continuous biogas digester plant, the loading and residue management is daily. Each loading on this digester requires a retention time, usually between 14 to 40 days. Continuous flow biogas digester allows a continuous supply of biogas and fertilizer and the continuous treatment of small amount of waste [2]. The material into this model need to be diluted hence, it is disadvantage. Continuously expanding flow biogas digester is one - third filled with bio wastes and the filled in stages and later emptied while plug flow biogas digester requires regular addition of the bio wastes at one end and over - flows at the other end.

Biogas cannot be used domestically directly because it is made up of ingredients like water vapor, hydrogen sulphide, carbon dioxide, and dirt particles. Therefore, it needs to be cleaned / purified before usage. The unwanted gases are removed to avoid corrosion of the inner parts of the appliances. Method of cleaning biogas includes; uses of biotrickling filters for removal of hydrogen sulphide. Biotricking method requires sulphur oxidixing bacteria that form a biofilm on an organic packing material inside the reactor/digester [4]. A scrubber (water scrubbing device) can also be used to clean biogas up to 95\% removal of carbon dioxide from biogas. Water scrubbing involves the physical absorption of $\mathrm{CO}_{2}$, water and $\mathrm{H}_{2} \mathrm{~S}$ that takes place in water at high regeneration by release of pressure with very little change in temperature [5]. Other materials substances that can be used for absorption process apart from water are polyethylene glycol, amineo [6]. Biogas can also be cleaned or filtered through membrane separation, cryogenic separation and chemical conversion [5].

Therefore, feasibility of producing biogas from biomass (cow dung) is presented in this paper and also, procedures and materials required for generating biogas as alternative fuel are enumerated for adoption in Nigeria.

\section{Anaerobic Digestion Process and Its Benefits in Nigeria}

\subsection{Anaerobic Digestion Process}

Anaerobic process is a biochemical process during which complex organic matter is decomposed in the absence of oxygen by various types of anaerobic microorganisms. The process is purely bacteria process that can be further divided into four phases, Hydrolysis, acidification, Acetification and Methanogenesis phase [7]. a. Hydrolysis: this the first phase in which the bacteria use enzymes to decompose high molecular compounds. The organic substances such as polysaccharide, protein and lipid that are mostly insoluble, complex and high molecular compounds are converted to mono - saccharide peptide, amino acids and fatty acids. These are further converted into soluble and low molecular compounds; acetate, propionate and butyrate.

b. Acidification Phase: acid formers micro organisms' facultative and anaerobic group hydrogen and ferment the water soluble substances produced in first stage into volatile acid. At this stage acetic acid is majorly produced and the addition of butyric acid and propionic acid.

c. Acidification Phase: products from acidification phase that cannot be directly converted to methane by methanogenic bacteria are converted into methanogenic substrates. Volatile Fatty Acids and Alcohol are oxidized into methanogenic substrate like acetate, hydrogen, and carbon dioxide. Acetogenesis and methanogenesis run parallel as symbiosis of two groups of organisms.

d. Methanogenic Phase: in methanogenic phase, products of acetification phase are converted to mixture of methane $\left(\mathrm{CH}_{4}\right)$, carbon dioxide $\left(\mathrm{CO}_{2}\right)$ by bacteria that are strictly anaerobes. Methanogenic phase is the critical phase of the entire anaerobic digestion process. It is severely influenced by operation parameters like feedstock composition, feeding rate, temperature and $\mathrm{PH}$ value. It is noted that overloading of the digester, large entry of oxygen or temperature changes can terminate the production of methane.

Acid former bacteria and methane ferment are must remain in a state of dynamic equilibrium. Methane bacteria need the metabolism products and the necessary conditions for both bacteria types are imperative for a smooth flow. One million metric tons of waste produced average 5.6 million $\mathrm{m}^{3}$ /year or $15,400 \mathrm{~m}^{3}$ /day of gas as quoted by Tom Fiesinger (2006). From USEPA Thermal Equivalent of various fuels, a dairy cow produces approximately $2.8 \mathrm{~m}^{3} /$ day or $1,022 \mathrm{~m}^{3} /$ year. The benefits of biogas generation could be for the society or and the farmers [7].

\subsection{Benefits for the Farmers}

i. It provides additional incomes for the farmers. Biogas production technology is economically attractive for farmers and provides them with additional incomes due to production of feedstock in combination with operation. It provides energy and as well waste treatment.

ii. It is a source of fertilizer, the digested substrate, usually named digestate is a valuable source of soil fertilizer rich in nitrogen, phosphorous, potassium and 
micronutrients, which can be applied to the soil for application of liquid manure. Digestate has higher homogeneity and nutrient availability; hence it has improved fertilizer efficiency compare to raw manure.

iii. Biogas has closed nutrient cycle and carbon cycle. Methane produced is used for energy production and the carbon dioxide is released to the atmosphere and re - uptake by vegetation during photosynthesis.

iv. Different types of feedstock can be used for the production of biogas, therefore is flexible. The feedstock also called substrata are animal manure and slurries, crop residue, organic waste from agro industries dairy production, food industries and agro industries, waste water sludge, organic fraction of municipal solid wastes, organic waste from catering business and from households. Interestingly, biogas production has the ability to use wet biomass as types of feedstock that characterized by moisture content higher than $60-70 \%$.

\subsection{Benefits for the Society}

i. Biogas is a source of renewable energy unlike energy from fossil fuel such as crude oil, lignite, hard coal and natural gas.

ii. Biogas generation reduces greenhouse gas emission and mitigation of global warming. Emission of methane and nitro oxide from stored methane and nitro oxide as well as utilization of untreated manure is reduced.

iii. Production of biogas from organic wastes reduces problems associated with over production of waste. Biogas production therefore considered as an excellent way of managing waste by recycling of the digested substrate as fertilizer. It reduces volume of waste and cost of waste disposal.

iv. Biogas production increases the income in rural and creates new jobs as production of biogas from anaerobic digestion requires work power. It requires construction works, fabrication of technical equipment, transportation of digester feedstock's, operation and maintenance of biogas plant.

v. Anaerobic digestion process needs low amount of process water. This is a great advantage even compared to other biofuels and no fear of water storage in future [7, 8, and 9].

\section{Biogas Generation}

\subsection{Site Location and Material Selection}

Construction site selection is considered important in order to minimized cost of construction, ensure easy operation and maintenance activities and guarantee plant safety.
Based on above consideration, it is hereby recommended that about $75 \%$ of below mentioned should be met:

a A Sunny Site - sunny site is preferable for effective functioning of the bio digesters. Temperature between $20-35^{\circ} \mathrm{C}$ has to be maintained inside the digester.

b Even Surface and Elevation Ground - the site should be even in surface and slightly higher in elevation than the surrounding to avoid water logging. It also ensures free flow of slurry from overflow outlet to the composting pit.

c Water Source - water source should not be far from the digester for mixing of dung. Also, the digester should at least be $10 \mathrm{~m}$ away from water source to prevent ground water pollution.

d Type of Soil - the soil should have enough bearing capacity to avoid the possibility of sinking of structure. Also, sufficient distance from trees and house foundation should be avoided.

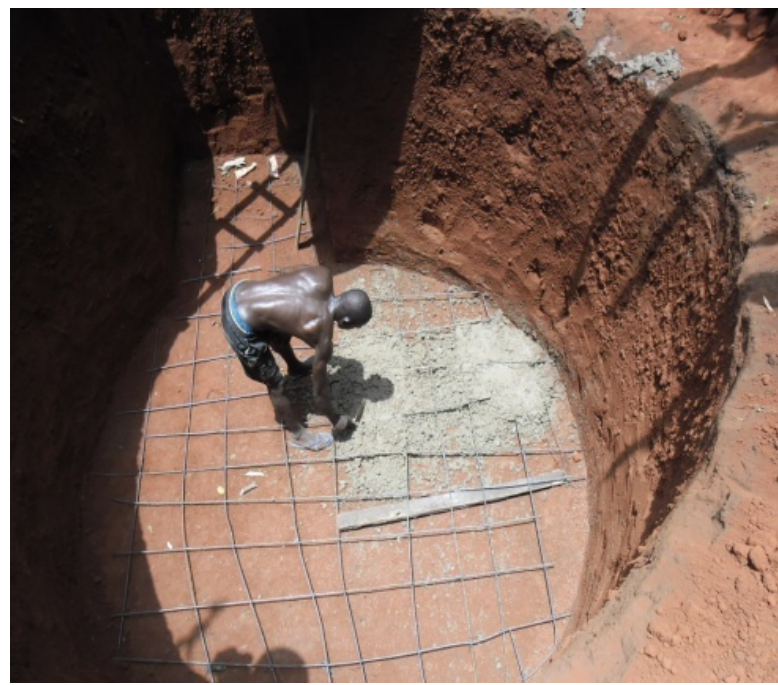

Figure 1. Excavated Pit Showing Basement Reinforcement

\subsection{Material Selection}

Even though, design of biodigester is correct and workmanship involved in construction is excellent, but if the construction materials used are of inferior quality, the biodigester will not function well. Hence, materials of best quality, preferred standard and specifications are described below:

\section{a Cement and Sand}

Cement to be used must be fresh, free from lumps and stored in dry place. The sand should not contain soil or other materials. Dirty sand has very negative effect on the strength of the structure. Therefore, sand that contains more than 3\% impurities must be washed. Generally, coarse and granular sand are best for concreting while fine sand has to be used for plastering works. 


\section{b Gravel}

Gravels to be used for biodigester should be cleaned, hard and of angular shape. The size should not be very big neither very small. It should be $25 \%$ or less than the thickness of the concrete product where it is used. For instance, if thickness of concrete layer of the wall is $130 \mathrm{~mm}$, hence the gravel size $=1 / 4 \times 130=$ $32.5 \mathrm{~mm}$

\section{c Water}

Water is important for making cement mortar for masonry works, concreting work and plastering. It is needed for cleaning and or washing construction materials if they are dirty. Clean water is recommended because dirty water has an adverse effect on the strength of structure.

\section{d Paint}

Paint used in bio digester construction is produced / formed from a mixture of raw cement and water. It used to make the gas holder and digester air - tight.

e Mild Steel Bars and Galvanized Metal Plate

Mild steel bars and galvanized metal sheets are used for preparation of form work for digester wall and also for reinforcement. $8 \mathrm{~mm}$ metal rod is used to support the form work/mould while quarter inch rod is used for reinforcement. Other materials needed are plywood, 2 by 2 plank used for gas holder form work.

\section{f Main Gas Pipe, Gas Valve, Pipes and Fittings}

Gas pipe is used to convey gas stored in the gas holder to the pipeline, it is placed in the topmost part of the portion of the dome. Note the joint reduction elbow with this pipe should be perfect and gas tight to avoid gas leakage. Gas pipe is properly galvanized to prevent rusting and this pipe should be at least $600 \mathrm{~mm}$ long. Gas valve controls the flow of gas in the pipeline from the gas filter/cleaner to the gas burner and gas lamp. The connection should be perfect and gas leakage free. Pipes/holes and fittings are made from high quality neoprene rubber. It conveys biogas from gas holder through gas cleaner to the point of application. The holes/pipe has $12 \mathrm{~mm}$ outer diameter and $9 \mathrm{~mm}$ inner diameter with minimum thickness of $2.5 \mathrm{~mm}$.

\subsection{Biogas Plant Components}

a. The Digester

The digester is structure of concrete (a mixture of cement, gravel, sand and water). Digester is cylindrical in shape buried in the ground with average operating temperature of $50^{\circ} \mathrm{C}$. It accommodates substrata and water. Anaerobic digestion takes place in the digester to generate methane, carbon dioxides and some trace gas. Digester should be gas tight since the appliances like burner and gas lamp require constant pressure supply.

\section{b. The Dome/Gas Holder}

This is the top part of the plant, it is a gas space and therefore gas tight. It is a structure of concrete, painted with a mixture of raw cement and water. The gas stored in the gas holder is conveying to the line through gas pipe. The pipe is about $600 \mathrm{~mm}$ long, galvanized to prevent rusting/corrosion. It is made up of light quality iron.

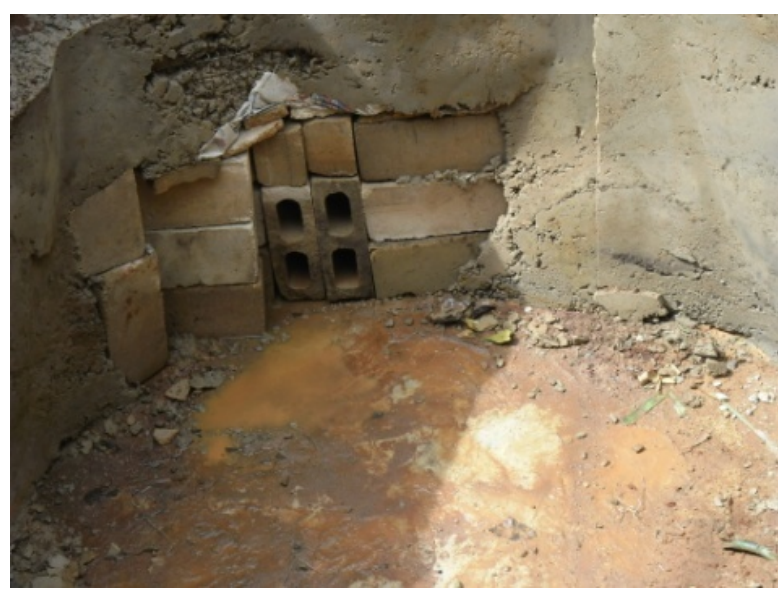

Figure 2. $\quad$ Digester Wall

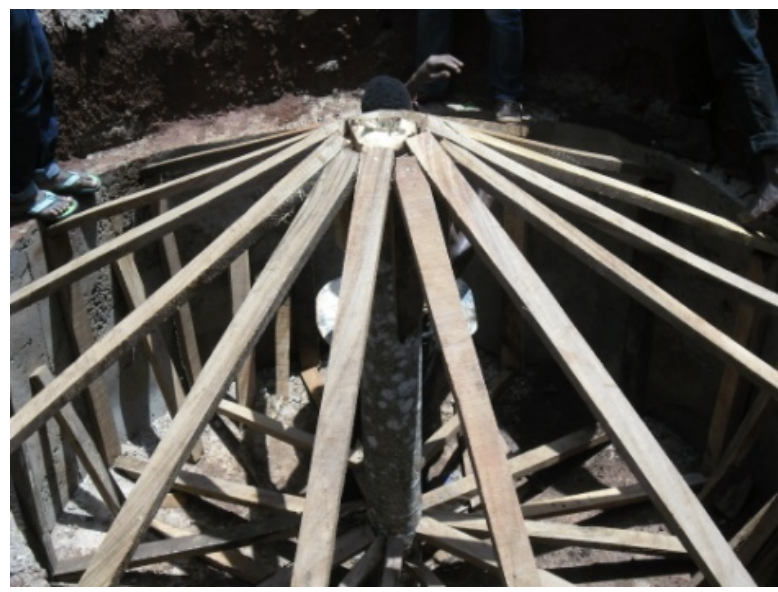

Figure 3. Gas Dome Work

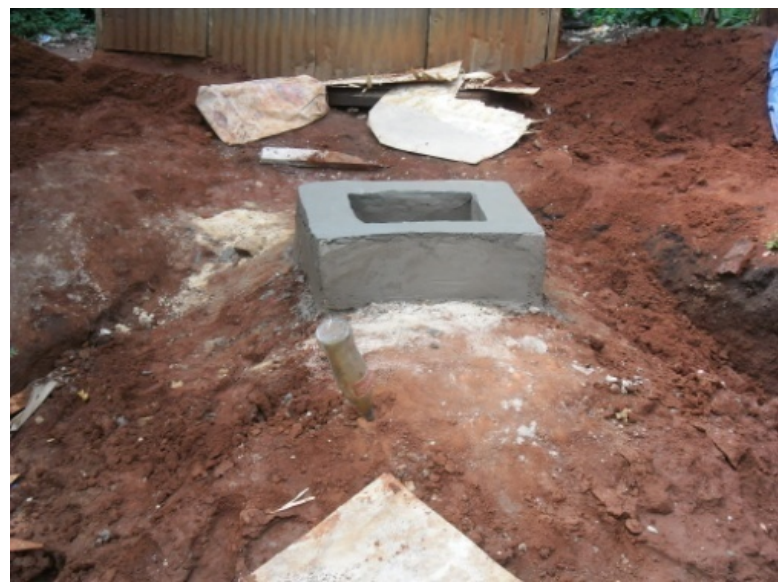

Figure 4. Dome Showing Mixing Tank 


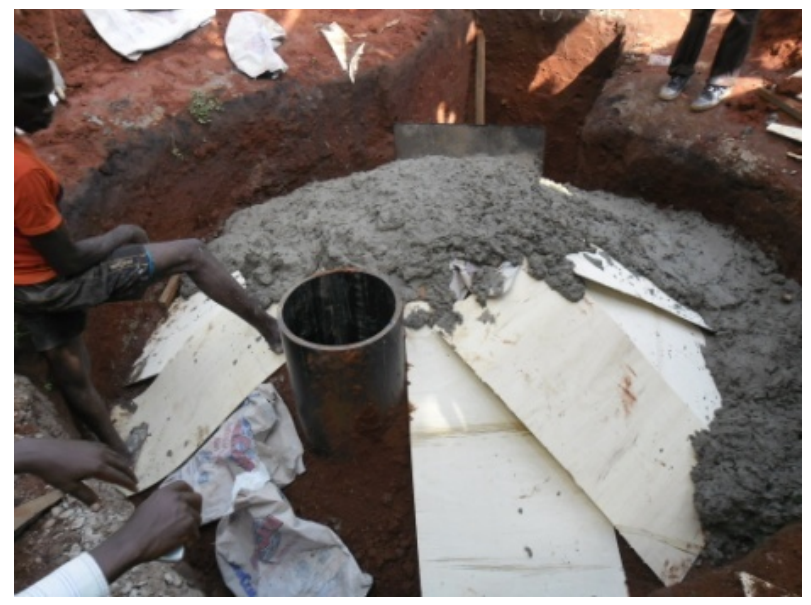

Figure 5. Dome Showing Inlet Pipe

c. Inspection Tank

Inspection tank is also referred to as compensation tank or displacement tank. It is a structure of cement block, plastered and painted to avoid leakage. It is use to compensate the digester after retention time has lapsed. Also, instead of the pressure built up by the gas to affect the structure, the water level in the inspection tank is displaced. It provides man hole into the digester for maintenance.

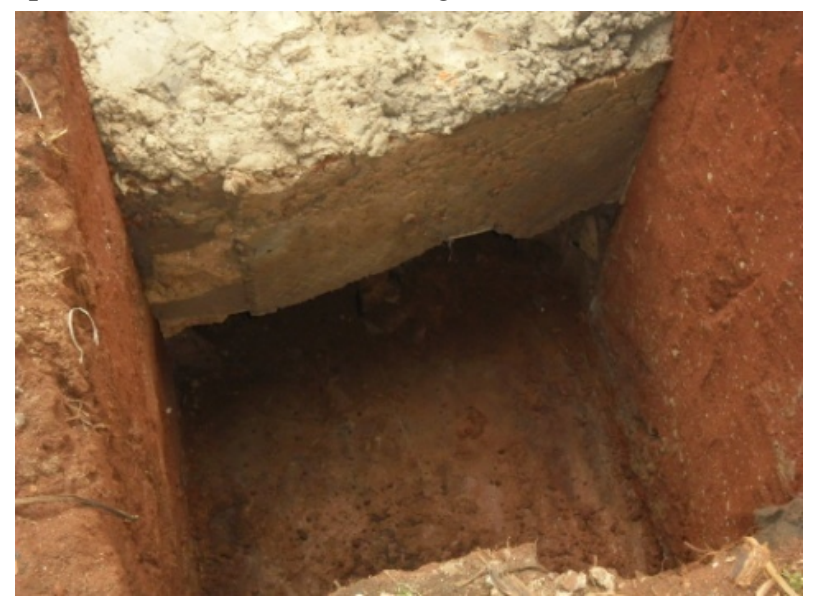

Figure 6. Inspection Tank and Man - Hole to Access Digester

\section{d. Rubber Hoses}

This is a special design hose for biogas; it is transparent and non-pressurized pipe. The hose is connected to the gas pipe on the gas holder. It conveys the gas to the applications i.e. gas burner and gas lamp.

\section{e. Gas Cleaner/ Filter}

Gas cleaner/ filter is a unit that cleans and filtered unwanted gases or materials such as water vapor, hydrogen sulphide, hydrogen and sulphur from the biogas. Gas cleaner is located in between the gas holder and application points.

\section{f. Gas Burner}

Gas Burner is a unit that uses the biogas generated for cooking. It comprises of burner, automated igniter, and the frame. The frame accommodates double burner, it has a knob used to allow the passage of gas into the system and also used to initiate spark that ignite the gas.

\section{g. Gas Lamp or Bulb}

Gas Lamp or Bulb is a unit made up of control valve, switch, and filament and glass shade. Metal frame accommodates the filament, tungsten net, igniter, and the glass shade. Flow of gas to the gas lamp is regulated by control valve for proper glowing and the switch initiate spark that glows the filament.

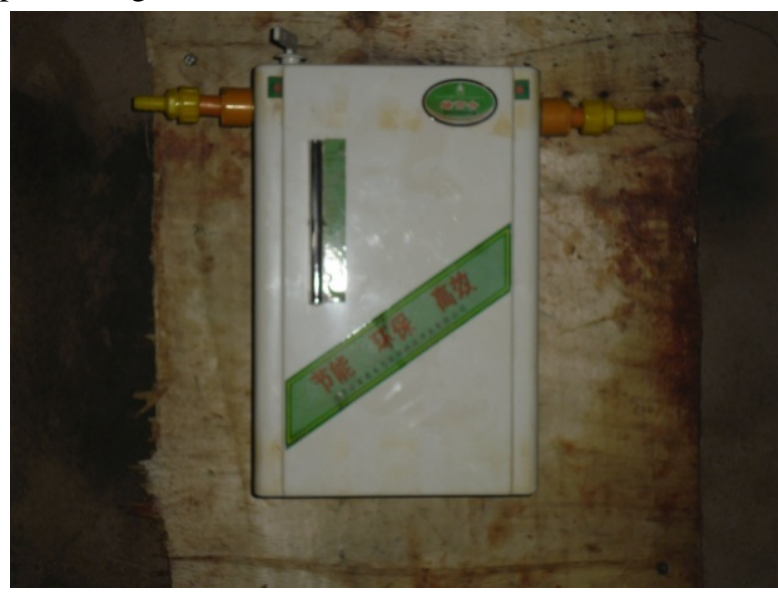

Figure 7. Gas Filter

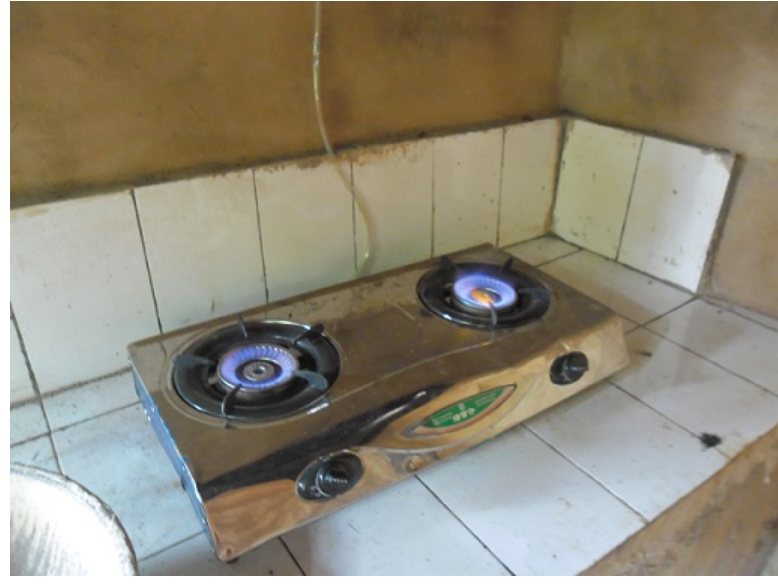

Figure 8. Biogas Burner

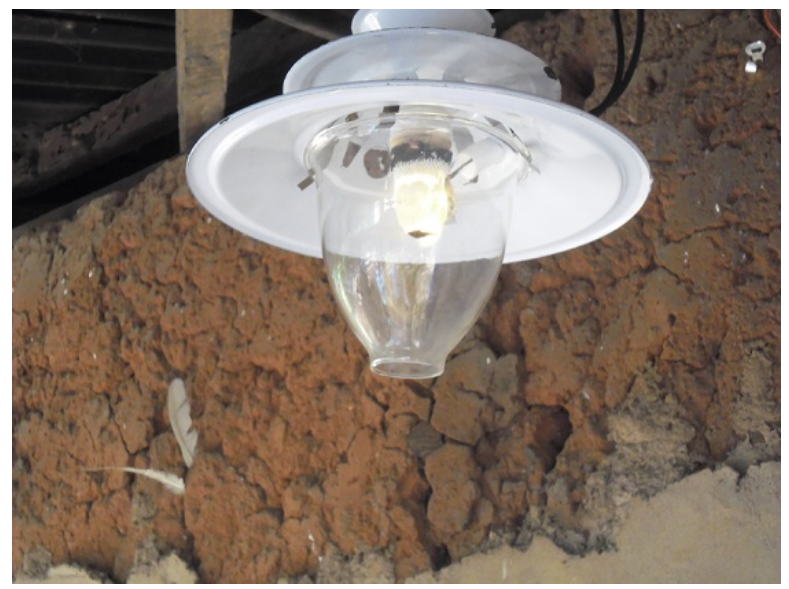

Figure 9. Biogas Lamp 


\section{Results and Discussion}

$10 \mathrm{~m}^{3}$ of slurry (a mixture of cow dung and water) that was loaded into the digester was left for 5 hrs after the water vapour has been allowed to escape from the dome. The Gas cleaner read $10 \mathrm{KPA}$, and the displaced water in the displacement tank read $800 \mathrm{~mm}$ the first day. The gas produced for the first day was calculated to be $8.5 \mathrm{~m}^{3}$, the gas was exhausted and the same procedure was repeated for 27 days to know the retention time of the plant. The upward displacement of the water in the displacement tank was as result of gas expansion in the dome that exerted force on the surface of the substrate that push up the water in the displacement or inspection tank. For the first 28 days, the pressure of the gas from day 1 to $13^{\text {th }}$ day remain constant at $10 \mathrm{KPA}$ and the volume of gas produced varied from $8.5-7.6 \mathrm{~m}^{3}$. The pressure started declining and water displacement from the inspection tank was not noted again till the pressure finally dropped to 3KPA at day $27^{\text {th }}$ and the system said to have reached retention day.

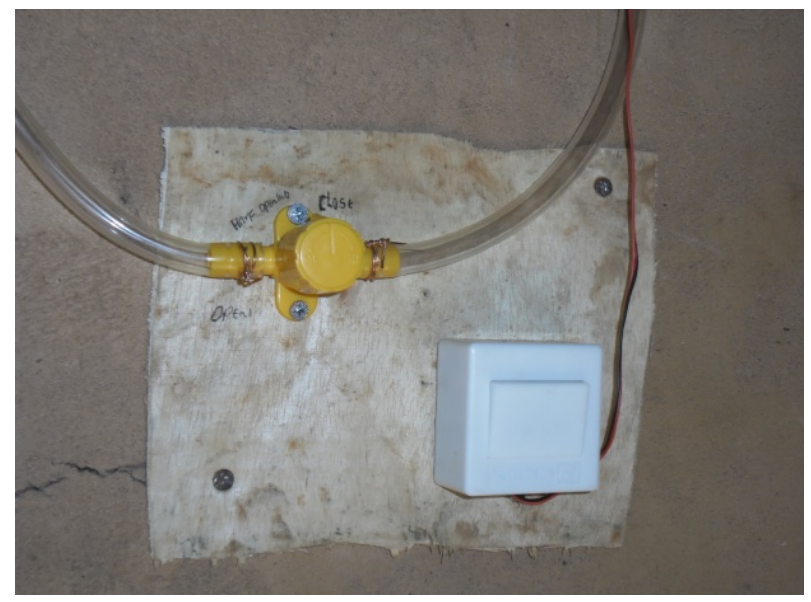

Figure 10. Biogas Lamp Control Knob

Table 1. Volume of Gas Produced for the first 28 Days Retention Time

\begin{tabular}{|c|c|c|c|c|c|}
\hline No of Days & $P(K P A)$ & $V_{\boldsymbol{D}}\left(\mathrm{m}^{3}\right)$ & $V_{I}\left(\mathrm{~m}^{3}\right)$ & $V_{E}\left(\mathrm{~m}^{3}\right)$ & $V_{G}\left(\mathrm{~m}^{3}\right)$ \\
\hline 1 & 10 & 7.4 & 0.052 & 1.152 & 8.5 \\
\hline 2 & 10 & 7.4 & 0.052 & 1.152 & 8.5 \\
\hline 3 & 10 & 7.4 & 0.052 & 1.152 & 8.5 \\
\hline 4 & 10 & 7.4 & 0.052 & 1.008 & 8.356 \\
\hline 5 & 10 & 7.4 & 0.052 & 1.008 & 8.356 \\
\hline 6 & 10 & 7.4 & 0.052 & 0.864 & 8.212 \\
\hline 7 & 10 & 7.4 & 0.052 & 0.864 & 8.212 \\
\hline 8 & 10 & 7.4 & 0.052 & 0.864 & 8.212 \\
\hline 9 & 10 & 7.4 & 0.052 & 0.576 & 7.924 \\
\hline 10 & 10 & 7.4 & 0.052 & 0.576 & 7.924 \\
\hline 11 & 10 & 7.4 & 0.052 & 0.288 & 7.636 \\
\hline 12 & 10 & 7.4 & 0.052 & 0.288 & 7.636 \\
\hline 13 & 10 & 7.4 & 0.052 & 0.288 & 7.636 \\
\hline 14 & 9 & Unestimated & 0.052 & Nil & Unestimated \\
\hline 15 & 9 & Unestimated & 0.052 & Nil & Unestimated \\
\hline 16 & 8 & Unestimated & 0.052 & Nil & Unestimated \\
\hline 17 & 8 & Unestimated & 0.052 & Nil & Unestimated \\
\hline 18 & 7 & Unestimated & 0.052 & Nil & Unestimated \\
\hline 19 & 8 & Unestimated & 0.052 & Nil & Unestimated \\
\hline 20 & 7 & Unestimated & 0.052 & Nil & Unestimated \\
\hline 21 & 7 & Unestimated & 0.052 & Nil & Unestimated \\
\hline 22 & 5 & Unestimated & 0.052 & Nil & Unestimated \\
\hline 23 & 5 & Unestimated & 0.052 & Nil & Unestimated \\
\hline 24 & 5 & Unestimated & 0.052 & Nil & Unestimated \\
\hline 25 & 3 & Unestimated & 0.052 & Nil & Unestimated \\
\hline 26 & 3 & Unestimated & 0.052 & Nil & Unestimated \\
\hline 27 & 3 & Unestimated & 0.052 & Nil & Unestimated \\
\hline \multicolumn{6}{|l|}{28} \\
\hline 29 & & & & & \\
\hline
\end{tabular}


After the retention time has reached, 6 - wheel barrow of the substrate was evacuated from the digester and replaced with equal volume of fresh substrate. The pressure started dropping from $10 \mathrm{KPA}$ as from day 11 till it has reached 3 KPA on day 26. This variation indicates decrease in activities of anaerobes in the digester.

Gas burner was ignited; it produced blue and odorless flame. The burner was used to boiled egg that took us 4 mins, 30 secs. House occupant/beneficiary used the system continuously for 2 hours and above before our team left site. Also, gas lamp was tested and glowed with very little inflow of gas to the system. This unit is left functioning (on) because it consumes little gas compare to gas burner.

Table 2. Volume of Gas Produced after the first 28 Days Retention Time

\begin{tabular}{|c|c|c|c|c|c|}
\hline No of Days & $P(K P A)$ & $V_{\boldsymbol{D}}\left(\mathrm{m}^{3}\right)$ & $V_{I}\left(\mathrm{~m}^{3}\right)$ & $V_{E}\left(\mathrm{~m}^{3}\right)$ & $V_{\boldsymbol{G}}\left(\mathrm{m}^{3}\right)$ \\
\hline 1 & 10 & 7.4 & 0.052 & 1.008 & 8.356 \\
\hline 2 & 10 & 7.4 & 0.052 & 1.008 & 8.356 \\
\hline 3 & 10 & 7.4 & 0.052 & 1.008 & 8.356 \\
\hline 4 & 10 & 7.4 & 0.052 & 0.72 & 8.068 \\
\hline 5 & 10 & 7.4 & 0.052 & 0.576 & 7.924 \\
\hline 6 & 10 & 7.4 & 0.052 & 0.432 & 7.78 \\
\hline 7 & 10 & 7.4 & 0.052 & 0.288 & 7.636 \\
\hline 8 & 10 & 7.4 & 0.052 & 0.144 & 7.492 \\
\hline 9 & 10 & 7.4 & 0.052 & Nil & 7.348 \\
\hline 10 & 10 & 7.4 & 0.052 & Nil & 7.348 \\
\hline 11 & 8 & Unestimated & 0.052 & Nil & Unestimated \\
\hline 12 & 9 & Unestimated & 0.052 & Nil & Unestimated \\
\hline 13 & 8 & Unestimated & 0.052 & Nil & Unestimated \\
\hline 14 & 8 & Unestimated & 0.052 & Nil & Unestimated \\
\hline 15 & 8 & Unestimated & 0.052 & Nil & Unestimated \\
\hline 16 & 7 & Unestimated & 0.052 & Nil & Unestimated \\
\hline 17 & 7 & Unestimated & 0.052 & Nil & Unestimated \\
\hline 18 & 6 & Unestimated & 0.052 & Nil & Unestimated \\
\hline 19 & 6 & Unestimated & 0.052 & Nil & Unestimated \\
\hline 20 & 6 & Unestimated & 0.052 & Nil & Unestimated \\
\hline 21 & 5 & Unestimated & 0.052 & Nil & Unestimated \\
\hline 22 & 3 & Unestimated & 0.052 & Nil & Unestimated \\
\hline 23 & 3 & Unestimated & 0.052 & Nil & Unestimated \\
\hline 24 & 3 & Unestimated & 0.052 & Nil & Unestimated \\
\hline 25 & 3 & Unestimated & 0.052 & Nil & Unestimated \\
\hline 26 & 3 & Unestimated & 0.052 & Nil & Unestimated \\
\hline \multicolumn{6}{|l|}{27} \\
\hline \multicolumn{6}{|l|}{28} \\
\hline 29 & & & & & \\
\hline
\end{tabular}

SOURCE: Analysis

$P(K P A)=$ Pressure of the Gas in the Gas Cleaner

$V_{D}=$ Volume of the Gas in the Gas Dome

$V_{I}=$ Volume Occupied by the Inlet Pipe in the Gas Dome

$V_{E}=$ Vol. of Gas Estimated From Displacement Tank

$V_{G}=$ Actual Vol. of Gas Produced Per Day 


\section{Conclusions}

From different types of biomass available in our environment that constitute nuisance, an alternative renewable energy can be produced to replace traditional hydrocarbon fuels. Anaerobic digestion treatment of biomass increase farmers income, serve as source of fertilizers, reduces emission of greenhouse gases and cost of waste disposal. If the recommended material specifications is strictly followed as stated/ mentioned in this paper, Engineer will constructs functional digester with higher efficiency. Biogas digester structure can last for hundred years.

\section{REFERENCES}

[1] National Domestic Biogas Programme (2007), 'Modified GGC Model Biogas Plant for Rwanda 2007’, Construction Manual.

[2] M. Sammer, 'Biogas Construction', Cairo University, Faculty of Agriculture, Department of Agricultural Engineering Egypt: Retrieved May, 2015; www.intechopen.com.

[3] Ferm Rela, Elena Jimenez, Elsabet Gonzalez, Jasme Cabre, Anna Ayats, Marianne Haberbause, Frances Borto, Lius Comella, Cristina Ribas, Gemma Gotor, Eusebi Roig and Nuria Vallmitjana, 'Energy Recovery from Landfills Biogas by the use of Microturbines and Biological Removal of Hydrogen Sulhpide and Siloxanes’. Retrieved May, 2015 from www.microphilox.com.

[4] J.I. Hurtas, N. Giraldo and S. Izquerdo, 'Removal of $\mathrm{H}_{2} \mathrm{~S}$ and $\mathrm{CO}_{2}$ from Biogas by Amine Absorption’, Mass Transfer in Chemical Engineering Proceses, Dr. Jozef MarkoAj (Ed) ISBN9789533076195, Intech, available from: http//www.intechopen.com/books/masstransfer-in-chemica l-engineering-proceses.

[5] Virenda K. Vijay, Ram Chandra, Parchuri M.V. Subbarao and Shan S. Kappdi (2006), 'Biogas Purification and Bottling into CNG cylinders’, Producing Bio - CNG from Biomass for Rural Automotive Applications. Paper Presented at 2nd Joint International Conference on Sustainable Energy and Environment, 21-23 November, 2006, Bangkok, Thailand.

[6] Henic-Peter Mang, 'Introduction to Ecological Sanitation', Introduction in the Technical Design for Anaerobic Treatment System and Dewarts. Retrieved May, 2015.

[7] N. de Arespacochaga, C. Mesa, A. Hornero, L. Bouuchy, E. Larrotch and C. Peregrina (retrieved May, 2015), 'Application Field of Biotricking Filters for Biogas $\mathrm{H}_{2} \mathrm{~S}$ Removal: Optimization of its Operating Conditions and Long Term Operation', International Water Association, World Congress on Water, Climate and Energy.

[8] Tom Fiesinger, Bruce. D. Roloson, Nbranan .R. Scott, Kimberly Bothi, Kelly Saikonean, Steven Zacari (2006), 'Biogas Processing', Report submitted to New York State Energy Research and Development Authority, Albary New York.

[9] Li Guochun (2015), 'Technical Manual for Biogas Digester Construction', Green Agriculture West Africa Ltd, CGC Rockwell Quarry Camp, Ushafa Junction, Bwari Road, Bwari District, FCT, Abuja. 